\title{
Perbandingan preferensi oviposisi lalat tentara hitam (Hermetia illucens) terhadap berbagai media penarik bertelur
}

\author{
Comparison of oviposition preference of black soldier fly (Hermetia illucens) on \\ different substrate as egg laying attractant
}

\author{
Rachel Anggia ${ }^{1}$, Ramadhani Eka Putra ${ }^{2 *}$ \\ 1) Program Studi Biologi, Sekolah Ilmu dan Teknologi Hayati, Institut Teknologi Bandung \\ Jalan Ganesha No. 10 Bandung, Indonesia 40116 \\ 2) Program Studi Rekayasa Pertanian, Sekolah Ilmu dan Teknologi Hayati, Institut Teknologi Bandung, Kampus Jatinangor \\ Jalan Let. Jen. Dr. (HC) Mashudi No. I Sumedang, Indonesia 45363 \\ *Email: ramadhani@sith.itb.ac.id
}

Diterima 20 Desember $2020 \quad$ Disetujui 2 September 2021

\section{INTISARI}

Lalat tentara hitam (Hermetia illucens) merupakan serangga yang sekarang digunakan sebagai salah satu agen hayati untuk mengendalikan limbah organik dengan merubahnya menjadi biomasa tubuh yang bernilai ekonomi. Dalam hal memaksimalkan kemampuan dari serangga ini, maka pemeliharaan buatan dan rekayasa siklus hidup lalat tentara hitam perlu dilakukan sehingga didapatkan proses pengurangan limbah organik yang optimal serta peningkatan biomassa panen. Salah satu faktor pembatas dalam pemanfaatan serangga ini dalam skala besar adalah pada produksi telur. Pada produksi telur digunakan perangkap telur yang dikombinasikan dengan media atraktan. Penggunaan perangkap telur dan media atraktan bertujuan untuk memfasilitasi panen telur agar lebih efektif karena telur akan terkonsentrasi pada satu lokasi. Pada penelitian ini dilakukan pengujian kinerja dari berbagai media atraktan dalam upaya mencari bahan yang paling optimal dalam menarik lalat tentara hitam meletakkan telur pada perangkap telur. Media atraktan yang digunakan adalah sayur kol busuk, buah pepaya busuk, ampas tahu dan pakan ikan. Kinerja media atraktan kemudian dievaluasi berdasarkan berat telur yang didapat pada perangkap telur. Studi ini melaporkan bahwa sebagian besar atraktan dapat menarik lalat tentara hitam. Berdasarkan hasil uji statistik dengan Kruskal-Wallis diketahui terdapat perbedaan signifikan pada berat telur yang didapat dari setiap atraktan yang digunakan dimana atraktran berupa tepung ikan merupakan atraktan yang paling efektif dengan berat telur rata-rata per perangkap adalah 2,17 gr. Di sisi lain atraktan yang terbuat dari ampas tahu merupakan atraktan yang paling tidak diminati dimana berat rata-rata telur per perangkap adalah $0,06 \mathrm{gr}$.

Kata kunci: Hermetia illucens, preferensi situs oviposisi, media atraktan

\begin{abstract}
Black soldier fly (Hermetia illucens) is one of the biological agents for organic waste decomposition. This process produced insect biomass with significant economic value. To maintain the population of this insect, an artificial rearing had to be done to produce a continuous supply of eggs. One of the important components of egg production is substrate to attract female to lay egg on the ovitraps. Ovitrap is a structure applied to accumulate the egg for easier handling. In this study, the preference of female on the several types of attractants was tested. The subtrates were rotten cabbage, rotten papaya, tofu dreg, and commercial fish
\end{abstract}


feed. The preference was based on the amounts of eggs laid on the ovitrap (in weight). The result showed that fish mill is the most preference substrate (amount of eggs: 2.17 gram) while tofu dreg was the least preferred substrate (amount of eggs: 0.06 gram).

Keywords: Hermetia illucens, attractant media, oviposition preferences

\section{PENDAHULUAN}

Lalat tentara hitam (Hermetia illucens) atau yang lebih dikenal sebagai black soldier fly (BSF) merupakan serangga dari ordo Diptera dengan famili Stratiomyidae (Diener et al., 2011) yang berasal dari benua Amerika dan mampu untuk tumbuh dengan baik pada wilayah dengan iklim tropis seperti di Indonesia (James, 1935). Lalat ini sekarang banyak dijadikan sebagai objek penelitian karena kemampuannya untuk mengkonsumsi berbagai jenis limbah organik (Kinasih et al., 2018; Abduh et al. 2018; Gao et al., 2019; Putra et al., 2020) dan merubahnya menjadi biomasa tubuh yang dapat memiliki kandungan protein hingga 50\% (Bosch et al., 2014) dan asam lemak mendekati 30\% (Pang et al., 2020) dari berat tubuh. Biomasa tubuh ini berpotensi sebagai bahan baku bagi produksi pakan bagi sistem akuakultur (Cummins et al., 2017; Magalhaes et al., 2017; Renna et al., 2017, Stadtlander et al., 2017; Belghit et al., 2019), peternakan unggas (Onsongo et al., 2018; Kawasaki et al., 2019; El-Hack et al., 2020), dan mamalia (Bosch et al., 2014; Driemyeer 2016;Dalle Zotte et al., 2018) serta bahan baku produksi biodiesel (Pang et al., 2020). Di sisi lain, residu yang dihasilkan memiliki potensi sebagai material untuk memperbaiki kualitas tanah (Beesigamukama et al., 2020; Klammsteiner et al., 2020). Hal ini menjadikan metoda pengolahan limbah organik menggunakan larva lalat tentara hitam memiliki potensi sebagai proses upcycling dari limbah organik sehingga dapat meningkatkan aktivitas pengolahan limbah organik.

Terkait dengan pemanfaatan kemampuan dari lalat ini, pada skala besar, dibutuhkan skema pemeliharaan buatan dibutuhkan. Beberapa penelitian menunjukkan terdapat tingkat konsumsi maksimum dari larva (Diener et al., 2009; Kinasih et al., 2018; Jucker et al., 2020) dan proses konversi hanya dilakukan pada tahapan larva sehingga kegiatan ini sangat tergantung pada jumlah telur yang dapat digunakan untuk memproduksi larva. Secara alami, lalat betina dewasa hanya kawin dan meletakkan telur satu kali dalam kehidupan mereka biasanya dua hari setelah proses kawin sukses dilakukan (Tomberlin \& Sheppard, 2002).Dalam kondisi ini, maka tahap produksi telur yang harus dilakukan secara artifisial (Pastor et al., 2015) yang memungkinkan telur untuk dapat diproduksi dan dikoleksi dalam jumlah besar sepanjang tahun sehingga proses pengolahan limbah dapat berlangsung secara kontinyu (Macavei et al., 2020). Beberapa penelitian telah menunjukkan bahwa tingkat produksi telur sangat dipengaruhi oleh nutrisi yang diterima induk saat larva (Gobbi et al., 2013; Pastor et al., 2015) dan setelah dewasa (Bertinetti et al., 2019; Lupi et al., 2019) serta kondisi lingkungan dari ruang pemeliharaan lalat dewasa (Hoc et al., 2019; Liu et al., 2020; Macavei et al., 2020).

Selain terkait dengan kondisi fisiologis dari lalat betina dewasa, dalam proses produksi telur terdapat satu komponen yang menjadi bagian tidak terpisahkan dari proses produksi telur pada kondisi lingkungan buatan, yaitu media atraktan dan perangkap telur (Sripontan et al., 2017). Kedua komponen tersebut dibutuhkan untuk mempermudah proses pemanenan karena telur akan terkonsentrasi pada satu lokasi. Secara alami, lalat betina akan mencari celah kering di atas subtrat lembab yang dapat memberikan keuntungan pada larvanya bagi tumbuh. Pada serangga, pemilihan situs oviposisi adalah tahap kritis karena larva yang baru menetas tidak mampu mencari makananya sendiri dan sangat bergantung pada senyawa organik yang terdapat pada lokasi oviposisi yang dipilih oleh lalat betina (Wint, 1983; Futuyma et al., 1984). 
Subtrat yang dipilih oleh induk pada umumnya merupakan limbah organik yang telah membusuk sehingga memiliki aroma yang kuat akan memikat lalat tentara hitam betina untuk bertelur pada perangkap telur yang diletakan di atasnya (Ewusie et al. 2019). Walaupun hal ini dianggap penting, akan tetapi masih minim ditemukan penelitian terkait dengan efek dari substrat terhadap preferensi dari induk betina terutama di Indonesia. Hal tersebut di atas menjadi dasar dari penelitian ini yang bertujuan untuk mendapatkan informasi terkait preferensi dari lalat tentara hitam betina terhadap berbagai pilihan media atraktan sebagai penarik untuk meletakkan telur (oviposisi).

\section{MATERI DAN METODE}

\section{Tempat dan waktu penelitian}

Penelitian dilakukan di Laboratorium Toksikologi, Sekolah Ilmu dan Teknologi Hayati, Institut Teknologi Bandung. Laboratorium ini sendiri memiliki rentang suhu harian antara 22$28^{\circ} \mathrm{C}$ dengan kelembaban antara $60-80 \%$

\section{Hewan Uji}

Pupa BSF yang digunakan berasal dari koloni yang dibiakkan pada Sekolah Ilmu dan Teknologi Hayati, Institut Teknologi Bandung. Lalat ini berasal dari larva yang dibesarkan pada media berupa pakan ikan dan pakan ayam komersial.

\section{Prosedur Penelitian}

Pupa lalat tentara hitam dimasukan ke dalam kandang pemeliharaan. Jumlah pupa yang dimasukan dihitung berdasarkan volume kandang yang digunakan yaitu sebesar $0,144 \mathrm{~m}^{3}$, kepadatan terbang lalat tentara hitam yaitu $5000 / \mathrm{m}^{3}$ serta tingkat kemunculan sebesar $80 \%$ (Dortmans et al., 2017). Berdasarkan hasil perhitungan didapatkan jumlah pupa yang digunakan per kandang kawin adalah 900 buah. Pupa tersebut disimpan pada suatu wadah yang gelap dan diberikan lubang untuk lalat keluar.
Penentuan preferensi atraktan dilakukan dengan memberikan berbagai pilihan atrakttan dalam satu perlakuan (free choice). Media atraktan yang digunakan pada penelitian ini adalah ampas tahu yang berasal dari produsen tahu pada daerah Bandung, pakan ikan berbentuk pelet (Beauty PP812 Premium Patee), pepaya busuk serta kol busuk yang diperoleh dari pasar tradisional di Bandung Utara, yang masingmasing dihaluskan lalu dicampurkan dengan air dengan perbandingan 4:1 (w/v). Sebanyak $125 \mathrm{gr}$ atraktan, masing-masing dimasukkan ke dalam wadah plastik. Media atraktan yang digunakan pada penelitian ini adalah media yang umum digunakan oleh para pembudidaya BSF. Wadah atraktan tersebut lalu ditutupi dengan kain tipis sehingga memungkinkan penyebaran bau tetapi mencegah lalat untuk menyentuh dan bertelur pada bahan perangkap. Media atraktan dibuat basah dan dijaga kelembapannya pada level minimal $60 \%$ selama penelitian berlangsung.

Selain wadah yang berisikan media atraktan, dimasukan juga wadah kosong sebagai kontrol negatif serta kain yang dibasahi dengan air untuk minum BSF. Sebagai struktur bertelur, tiga buah kayu direkatkan dengan karet dan diletakan di atas wadah plastic yang berisi atraktan (Gambar 1). Celah di antara kayu berfungsi sebagai slot oviposisi untuk lalat tentara hitam. Pada penelitian ini dilakukan tiga kali pengulangan pengambilan data dan koleksi data dilakukan setiap hari hingga seluruh lalat mati. Kinerja dari media atraktan dievaluasi berdasarkan telur yang terdapat pada perangkap telur. Telur yang ada ditimbang beratnya setiap empat hari sekali menggunakan timbangan analitik.

\section{Analisis Statistik}

Data pertumbuhan yang diperolah kemudian dilakukan analisis statistik melalui uji One-way ANOVA (Analysis of Variance), kemudian dilanjutkan dengan uji Kruskal-Wallis dengan taraf kepercayaan 95\% ( $\mathrm{P}<0,05)$ menggunakan aplikasi SPSS versi 22 dengan tujuan untuk menentukan apakah ada perbedaan yang berarti dari setiap perlakuan. 

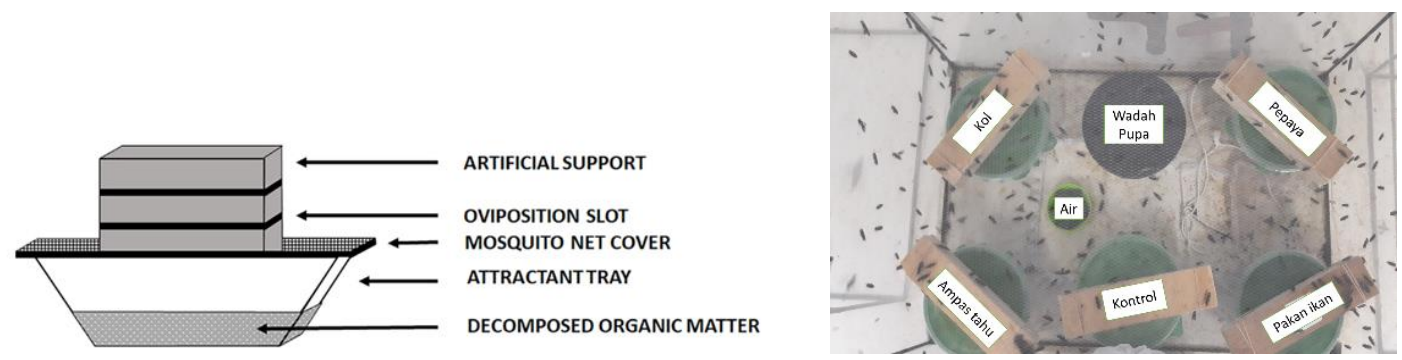

Gambar 1. Kiri: skema perangkap telur, kanan: penempatan perangkap telur pada kendang kawin (Hoc dkk., 2019)

\section{HASIL}

Secara umum, telur mulai dihasilkan pada pengambilan data ke-2 atau hari keempat. Puncak dari produksi telur yaitu pada pengambilan data ke-3 yaitu sebesar 1,08 gr. Hal ini dikarenakan puncak munculnya lalat dari pupa terjadi diantara periode pengambilan data ke-1 dan dua. Selama delapan kali pengambilan data, diketahui bahwa berat rata-rata total telur yang didapat dari semua atraktan adalah 2,92 gr (Gambar 2)

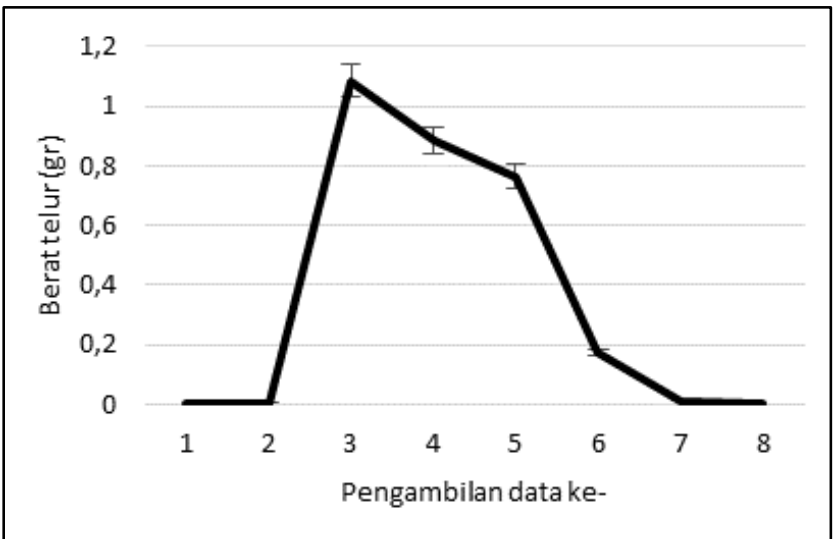

Gambar 2. Rata-rata total berat telur pada setiap waktu pengambilan data

Kinerja atau preferensi lalat tentara hitam terhadap media atraktan kemudian dievaluasi berdasarkan berat telur yang didapat pada masing-masing perangkap. Secara umum, seluruh atraktan dapat menarik lalat tentara hitam betina untuk meletakkan telur. Namun, pakan ikan merupakan atraktan yang paling efektif karena mendapatkan berat telur terbanyak yaitu dengan rata-rata sebesar 2,17 gr (setara dengan 74\% preferensi dengan atraktan berupa ampas tahu adalah yang paling sedikit yaitu 0,06 gr (Gambar 3). Hasil uji statistik Kruskal - Wallis menunjukan terdapat perbedaan yang berarti dari berat telur yang berada pada setiap atraktan yang digunakan. Hal ini menunjukan bahwa oviposisi terjadi tidak secara acak.

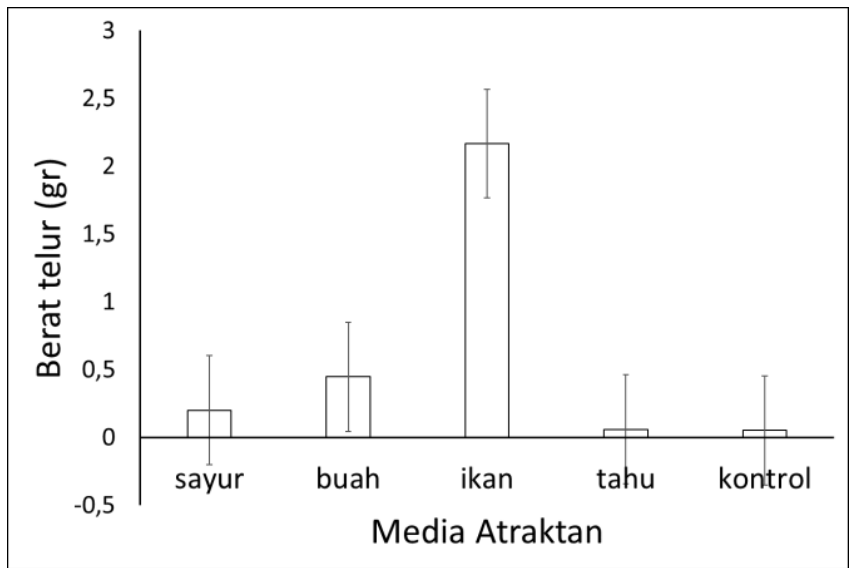

Gambar 3. Perbandingan berat telur pada berbagai media atraktan

\section{PEMBAHASAN}

Proses peletakan telur oleh induk betina BSF mengalami puncak pada hari ke-3 yang serupa dengan hasil penelitian Tomberlin \& Sheppard (2002) yang dilakukan pada daerah temperata. Data ini setidaknya mengindikasikan bahwa proses peletakan telur tidak dipengaruhi oleh strain dari lalat. Puncak peletakan telur terkait dengan waktu dari pematangan telur yang membutuhkan waktu hingga 2 hari (Julita et al., 2020). Beberapa penelitian melaporkan bahwa proses peletakan dari telur oleh induk betina BSF dipengaruhi oleh faktor cadangan nutrisi pada tubuh induk (Tomberlin \& Sheppard, 2002), intensitas dan panjang gelombang cahaya (Heussler et al., 2018), dan kepadatan dari serangga dewasa (Park et al., 2016). 
Penelitian ini menunjukkan, dengan mempertimbangkan bahwa lalat betina berasal dari kelompok yang sama, dipelihara pada kendang yang sama dengan kepadatan yang telah ditentukan, bahwa lalat tentara hitam mampu membedakan dan memiliki preferensi tertentu untuk menentukan lokasi bertelur walau terdapat noise karena terdapat berbagai stimulus, berupa aroma dari atraktan, yang diterima secara bersamaan (Singer; 1986; Thompson, 1988) dan ini memberikan efek pada jumlah telur yang dapat dikoleksi. Seperti sebagian besar serangga, induk betina menggunakan volatile yang dihasilkan oleh substrat untuk mendeteksi lokasi dari tempat peletakan telur yang ideal (Booth \& Sheppard, 1984; Carraher et al. 2015; Ewusie et al., 2019). Materi organik yang telah membusuk tersebut diketahui mengandung senyawa-senyawa volatil seperti etanol, aseton, etil asetat, dan senyawa alkohol lainnya (Wilkins, 1994). Senyawasenyawa volatil tersebut kemudian akan dikenali oleh lalat betina dewasa sebagai sinyal sumber makanan untuk keturunannya (Sripontan \& Chiu, 2017). Berdasarkan literatur, berikut merupakan senyawa volatil utama yang terdapat pada atraktan yang digunakan: trimethylamine pada pakan ikan (Ólafsdóttir, 2005), ammonia pada ampas tahu (Faisal et al., 2014), ethyl butanoate pada pepaya (Pino, 2014) serta methyl mercaptan pada sayur kol (Chin \& Lindsay, 1993). Senyawasenyawa inilah yang diduga dideteksi lalat dalam penentuan situs oviposisi. Pada lalat, pelepasan senyawa ini kemungkinan berkaitan dengan jenis mikroorganisme yang akan berasosiasi dengan mereka (Ashworth \& Wall, 1994; Lam et al., 2007; Chaudhury et al., 2010; Zheng et al., 2013). Hal ini mungkin dapat menjelaskan perbedaan dari efisiensi dari media atraktan dengan bahan yang sama dapat memiliki efek yang berbeda pada strain dari lokasi yang berbeda (Nyakeri, 2017).

Pemilihan situs oviposisi adalah tahap kritis pada serangga holometabolisme. Kesintasan dari keturunan lalat sangat bergantung pada sumber daya makanan yang ada dimana lalat betina meletakkan. Berdasarkan teori evolusi, lalat akan bertelur lebih banyak pada lokasi dimana tingkat kelangsungan hidup larva paling tinggi (Singer, 1986). Hal ini kemungkinan berkaitan dengan hubungan antara pengalaman yang dimiliki induk saat masa pra-imago sebagaiman dilaporkan pada beberapa kelompok serangga (Wang \& Mo, 2009; Karolewski et al., 2017). Hal ini dapat menjawab kemungkinan lainnya mengapa media pakan ikan, yang mirip dengan pakan ayam komersial yang merupakan pakan yang diberikan saat proses pertumbuhan dan perkembangan larva sebelum pupa, merupakan substrat yang paling disukai walau penelitian lebih lanjut dibutuhkan untuk menguji hipotesis ini.

\section{SIMPULAN}

Induk betina dari lalat tentara hitam memiliki preferensi tertentu terhadap media peletakkan telur. Berdasarkan hasil penelitian, pakan ikan merupakan atraktran peletakan telur terbaik.

\section{UCAPAN TERIMA KASIH}

Penelitian ini sebagian dibiayai, terkait dengan publikasi, oleh hibah penelitian Insinas 2021 dengan nomor 8/INS/PPK/E4/2021 yang diterima oleh penulis korespodensi.

\section{KEPUSTAKAAN}

Abduh MY, Nadia MH, Manurung R, Putra RE. 2018. Factors affecting the bioconversion of Philippine tung seed by black soldier fly larvae for the production of protein and oilrich biomass. Journal of Asia-Pacific Entomology 21(3): 836-842.

Ashworth JR, Wall R. Response of the sheep blowflies Lucilia sericata and Lucilia cuprina to odour and the development of semiochemical baits. Medical and Veterinary Entomology 8: 303-309.

Belghit I, Liland NS, Gjesdal P, Biancarosa I, Menchetti E, Li Y, Waagbo R, Krogdahl A, Lock EJ. 2019. Black soldier fly larvae meal can replace fish meal in diets of sea-water phase Atlantic salmon (Salmo salar). Aquaculture 503: 609-619.

Beesigamukama D, Mochoge B, Korir NK, Fiaboe KKM, Nakimbugwe D, Khamis FM, 
Subramanian S, Dubois T, Musyoka MW, Ekesi S, Kelemu S, Tanga CM. 2020. Exploring black soldier fly frass as novel fertilizer for improved growth, yield, and nitrogen use efficiency of maize under field conditions. Frontiers in Plant Science 11; 574592.

Bertinetti C, Samayoa AC, Hwang SY. 2019. Effects of feeding adults of Hermetia illucens (Diptera: Stratiomyidae) on longevity, oviposition, and egg hatchability: Insights into optimizing egg production. Journal of Insect Science 19(1): 19.

Booth DC, Sheppard DC. 1984. Oviposition of the black soldier fly, Hermetia illucens (Diptera: Stratiomyidae): eggs, masses, timing, and site characteristics. Environmental.Entomology 13: 421-423.

Bosch G, Zhang S, Dennis GABO, Wouter HH. 2014. Protein quality of insects as potential ingredients for dog and cat foods. Journal of Nutritional Science 3:1-4.

Carraher C; Dalziel J; Jordan MD.; Christie, DL.; Newcomb, RD.; Kralicek, AV. 2015. Towards an understanding of the structural basis for insect olfaction by odorant receptors. Insect Biochemistry and Molecular Biology 66: 31-41.

Chaudhury MF, Skoda SR, Sagel A, Welch JB. 2010. Volatiles emitted from eight woundisolated bacteria differentially attract gravid screwworms (Diptera: Calliphoridae) to oviposit. Journal of Medical Entomology 47: 349-354.

Chin HW, Lindsay R. 1993. Volatile sulfur compounds formed in disrupted tissues of different cabbage cultivars. Journal of Food Science 58(4): 835-839.

Cummins V, Rawles SD, Thompson K, Velasquez A, Kobayashi Y, Hager J, Webster C. 2017. Evaluation of black soldier fly (Hermetia illucens) larvae meal as partial or total replacement of marine fish meal in practical diets for Pacific white shrimp (Litopenaeus vannamei). Aquaculture 473: 337-344.

Dalle Zotte A, Cullere M, Martins C, Alves SP, Freire JPB, Falcao-E-Cunha L, Bessa RJB. 2018. Incorporation of black soldier fly (Hermetia illucens L.) larvae fat or excluder linseed in diet of growing rabbits and their effect on meat quality traits including detailed fatty acid composition. Meat Science 146: $50-58$.

Diener S, Zurbrugg C, Tockner K. 2009. Conversion of organic material by black soldier fly larvae: establishing optimal feeding rates. Wasta Management \& Research 27(6):603-610.

Diener S, Solano NMS, Gutiérrez FR, Zurbrügg C,Tockner K. 2011. Biological treatment of municipal organic waste using black soldier fly larvae. Waste and Biomass Valorization 2(4):357-63.

Dortmans BMA, Diener S, Verstappen BM, Zurbrügg C.2017. Black Soldier Fly Biowaste Processing - A Step-by-Step Guide Eawag: Swiss Federal Institute of Aquatic Science and Technology, Dübendorf, Switzerland

Driemeyer H. 2016. Evaluation of black soldier fly (Hermetia illucens) larvae as an alternative protein source in pig creep diets in relation to production, blood and manure microbiology parameters. Thesis (MScAgric)--Stellenbosch University, 2016., (December), 1-114.

El-Hack MEA, Shafi ME, Alghamdi WY, Abdelnour SA, Shehata AM, Noreldin AE, Ashour EA, Swelum AA, Al-Sagan AA, Alkhateeb M, Taha AE, Abdel-Moneim AME, Tufarelli V, Ragni M. 2020. Black soldier fly (Hermetia illucens) meal as a promising feed ingredient for poultry: A comprehensive review. Agriculture 10: 339.

Ewusie EA, Kwapong PK, Ofosu-Budu G, Sandrock C, Akumah AM, Nartey EK, Tetegaga C, Agyakwah SK. 2019. The black soldier fly, Hermetia illucens (Diptera: Stratiomyidae): Trapping and culturing of wild colonies in Ghana. Scientific African 5: e00134.

Faisal M, Machdar I, Maulana F, Daimon H. 2014. Potential renewable energy from tofu processing waste in Banda Aceh City, Indonesia. Asian Journal of Chemistry 26(19): 6601-6604.

Futuyma DJ, Cort RP, Noordwijky IV. 1984. Adaption to host plants in the fall cankerworm (Alsophila pometaria) and its bearing on the evolution of host affiliation in 
phytophagous insects. American Naturalist 123:287-296.

Gao Z, Wang W, Lu X, Zhu F, Liu W, Wang X, Lei C. 2019. Bioconversion performance and life table of black soldier fly (Hermetia illucens) on fermented maize straw. Journal of Cleaner Production 230: 974-980.

Gobbi P, Martínez-Sánchez A, Rojo S. 2013. The effects of larval diet on adult life-history traits of the black soldier fly, Hermetia illucens (Diptera: Stratiomyidae). European Journal of Entomology 110(3): 461.

Heussler CD, Walter A, Oberkofler H, Insam H, Arthofer W, Schlick-Steiner BC, Steiner FM. 2018. Influence of thress artificial light sources on oviposition and half-lifa of the Black Soldier Fly, Hermetia illucens (Diptera: Stratiomyidae): Improving smallscale indoor rearing. PLoS One 13(5): e0197896

Hoc B, Noel G, Carpentier J, Francis F, Megido RC. 2019. Optimization of black soldier fly (Hermetia illucens) artificial reproduction. PLoS One 14(4): e0216160.

James TM. 1935. The genus Hermetia in the United States (Diptera, Stratiomyidae). Bulletin of the Brooklyn Entomological Society 30: $165-170$

Jucker C, Lupi D, Moore CD, Leonardi MG, Savodelli S. 2020. Nutrient recapture from insect farm waste: Bioconversion with Hermetia illucens (L.) (Diptera: Stratiomyidae). Sustainability 12:362.

Julita U, Fitri LL, Putra RE, Permana AD. 2020. Mating success and reproductive behavior of black soldier fly Hermetia illucens L. (Diptera, Stratiomyidae) in tropics. Journal of Entomology 17:117-127.

Karolewski P, Lukowski A, Walczak U, Baraniak E, Mucha J, Giertych MJ. 2017. Larval food affects oviposition preference, female fecundity and offspring survival in Yponomeuta evonymellus. Ecological Entomology 42(5): 657-667.

Kawasaki K, Hashimoto Y, Hori A, Kawasaki T, Hirayasu H, Iwase S, Hashizume A, Ido A, Miura C, Miura T, Nakamura S, Seyama T, Matsumoto Y, Kasai K, Fujitani Y. 2019. Evaluation of black soldier fly (Hermetia illucens) larvae and pre-pupae raised on household organic waste, as potential ingredients for poultry feed. Animals 9(3): 98.

Kinasih I, Putra RE, Permana AD, Gusmara FF, Nurhadi MY, Anitasari RA. 2018. Growth performance of black soldier fly larvae (Hermetia illucens) fed on some plant based organic wastes. HAYATI Journal of Biosciences 25(2): 79-84.

Klammsteiner T, Turan V, Juarez MFD, Oberegger S, Insam H. 2020. Suitability of black soldier fly frass as soil amendment and implication for organic waste hygienization. Agronomy 10: 1578.

Lam K, Babor D, Duthie B, Babor EM, Moore M, Gries G. 2007. Proliferating bacterial symbionts on house fly eggs affect oviposition behaviour of adult flies. Animal Behaviour 74(1): 81-92.

Liu Z, Najar-Rodriguez AJ, Minor MA, Hedderley DI, Morel PCH. 2020. Mating success of the black soldier fly, Hermetia illucens (Diptera: Stratiomyidae), under four artificial light sources. Journal of Photochemistry and Photobiology B: Biology 205: 111815.

Lupi D, Savoldelli S, Leonardi MG, Jucker C. 2019. Feeding in the adult of Hermetia illucens (Diptera : Stratiomyidae): reality or fiction? Journal of Entomological and Acarological Research 51: 8046.

Macavei LI, Benassi G, Stoian V, Maistrello L. 2020. Optimization of Hermetia illucens (L.) egg laying under different nutrition and light condition. PLoS One 15(4): e0232144.

Magalhães R, Sánchez-López A, Leal R, Martínez-Llorens S, Olivia-Teles A, Peres H, 2017. Black soldier fly (Hermetia ilucens) pre pupae meal as a fish meal replacement in diets for European seabass (Dicentrarchus labrax). Aquaculture 476: 79-85.

Nyakeri E, Ogola H, Amemo F, Ayieko M. 2017. Comparison of the performance of different baiting attractants in the egg laying activity of the black soldier fly (Hermetia illucens L.) Journal of Entomology and Zoology Studies 5(6): 1583-1586

Olafsdottir G, Jonsdottir R, Lauzon HL, Luten J, Kristbergsson K. 2005. Characterization of volatile compounds in chilled cod (Gadus morhua) fillets by gas chromatography and detection of quality indicators by an 
electronic nose. Journal of Agricultural and Food Chemistry 53(26): 10140-10147.

Onsongo VO, Osuga IM, Gachuiri CK, Wachira AM, Miano DM, Tanga CM, Ekesi S, Nakimbugwe D, Fiaboe KKM. 2018. Insects for income generation through animal feed: effect of dietary replacement of soybean and fish meal with black soldier fly meal on broiler growth and economic performance. Journal of Economic Entomology 111: 19661973.

Pang W, Hou D, Ke J, Chen J, Holtzapple MT, Tomberlin JK, Chen H, Zhang J, Li Q. 2020. Production of biodiesel from $\mathrm{CO}_{2}$ and organic wastes by fermentation and black soldier fly. Renewable Energy 149: 11741181.

Park K, Kim W, Kim E, Choi JY, Kim SH. 2016. Effect of adult population density on egg production in the black soldier fly, Hermetia illucens (Dipter: Stratiomyidae). International Journal of Industrial Entomology 33(2): 92-95.

Pastor B, Velasquez Y, Gobbi P, Rojo S. 2015. Conversion of organic wastes into fly larval biomass: bottlenecks and challenges. Journal of Insects as Food Feed 1(3): 179-93.

Pino JA. 2014. Odour-active compounds in papaya fruit cv. Red Maradol. Food Chemistry 146: 120-126.

Putra RE, Margareta A, Kinasih I. 2020. The digestibility of banana peel and testa coconut and its effect on the growth and mortality of black soldier fly larvae (Hermetia illucens) at constant feeding rates. Biosfer : Jurnal Tadris Biologi 11(1): 66-77.

Renna M, Schiavone A, Gai F, Dabbou S, Lussiana C, Malfatto V, Prearo M, Capucchio MT, Biasato I, Biasibetti E, De Marco M, Brugiapaglia A, Zoccarato I, Gasco L. 2017. Evaluation of the suitability of a partially defatted black soldier fly (Hermetia illucens L.) larvae meal as ingredient for rainbow trout (Oncorhynchus mykiss Walbaum) diets. Journal of Animal Science and Biotechnology 8: 57.

Singer MC. 1986. The definition and measurement of ovipo-sition preference. Plant-Insect Interactions, (eds J. Miller \&T.A. Miller), pp 65-94. Springer-Verlag, Berlin.
Sripontan Y, Juntavimon T, Songin S, Chiu CI. 2017. Egg-trapping of black soldier fly, Hermetia illucens (L.) (Diptera: Stratiomyidae) with various wastes and the effects of environmental factors on egglaying Khon Kaen Agricultural Journal 45(1): 179-184.

Standtlander T, Stamer A, Buser A, Wohlfahrt J, Leiber F, Sandrock C. 2017. Hermetia illucens meal as fish meal replacement for rainbow trout on farm. Journal of Insects as Food and Feed 3: 165-175.

Thompson JN. 1988. Evolutionary ecology of the relationship between oviposition preference and performance of offspring in phytophagous insects. Entomologia Experimentalis Et Applicata 47(1): 3-14.

Tomberlin JK, Sheppard DC. 2002. Factor influencing mating and oviposition of Black Soldier Fly (Diptera: Stratioyidae) in a colony. Journal of Entomological Science 37(4): 345-352.

Wang ZY, Mo JC. 2009. Effects of Experience on Subsequent Feeding or Oviposition Preference in Musca domestica (Diptera: Muscidae) and Chrysomya megacephala (Diptera: Calliphoridae). Journal of Entomological Science 44(3): 187-192.

Wilkins K. 1994. Volatile organic compounds from household waste. Chemosphere 29(1): 47-53.

Wint W. 1983. The role of alternative host-plant species in the life of a polyphagous moth, Operophtera brumata (Lepidoptera: Geometridae). Journal of Animal Ecology 52:439-450.

Zheng L, Crippen TL, Holmes L, Singh B, Pimsler ML, Benbow ME, Tarone AM, Dowd S, Yu Z, Vanlaerhoven SL, Wood TK, Tomberlin JK. 2013. Bacteria mediate oviposition by the black soldier fly, Hermetia illucens (L.), (Diptera: Stratiomyidae). Scientific Reports 3: 2563. 